\title{
Physicochemical Determination of Pollutants in Wastewater in Dheradun
}

\author{
SACHCHIDA NAND SINGH ${ }^{1}$, GAURAV SRIVASTAV and ARUN BHATT* \\ Department of Chemistry S.G.G. ( P.G.) College, Dobhi, Jaunpur - 222149 (India) \\ Department of Biotechnology G.B. Pantt Engineering College Gurdahuri, Pauri Garhwal, (India).
}

(Received: April 03, 2012; Accepted: May 13, 2012)

\begin{abstract}
Wastewater was collected from the Dheradun industrial area situated in capital of uttrakhand. Samples were collected between the periods of November 2010 to Aug.2011 determine the following parameters, $\mathrm{pH}$, temperature, turbidity, chemical oxygen demand (COD), Biological oxygen demand(BOD), dissolved oxygen (DO), conductivity, total dissolved solid (TDS), total suspended solid (TSS), sulphate, nitrate, nitrite and phosphate. In addition, metals (copper, cobalt Chromium, iron, manganese, magnesium, nickel cadmium, lead, sodium, potassium and calcium were determined. Levels of $\mathrm{pH}$, conductivity, temperature, nitrate, nitrite, sulphate , phosphate, TSS, TDS, DO, BOD and COD were higher than the maximum permissible limits set by Bureo of Indian Standard Delhi. The concentrations of the metals in the wastewater were higher limits set by W.H.O. and the maximum contaminant levels (MCL Thus, the wastewater around the Dheradun industrial highly polluted. Domestic and industrial waste should be properly disposed and or recycled. Relevant agencies should make continuous effort to control, regulate and educate populace on indiscriminate waste disposal from domestic and industries within the study area. Physicochemical Determination of Pollutants in Wastewater.
\end{abstract}

Keywords: Physicochemical, Pollutant, Industrial Wastewater, Dheradun.

\section{INTRODUCTION}

Heavy metals are present in food in very minute quantities; the existence is due to their role in body metabolism, it has been establish that whatever is taken as food might cause metabolic disturbance if it does not contain the permissible upper and lower limits of heavy metals. Thus, both deficiency and excess of essential micro-nutrients (iron, zinc and chromium) may produce undesirable effects (Konofal et al., 2004; Kocak et al., 2005). Effect of toxic metals on human health and their interactions with essential heavy metals may produce serious consequences (Abdulla and Chmielnicka, 1990).From this viewpoint, metals such as iron, lead, chromium, nickel, arsenic and cadmium are considered suitable for studying the impact of various foods on human health. Arsenic occurs naturally in food at concentration levels, which are rather essential.

Wastewater discharge from sewage and industries are major component of water pollution,
Contributing to oxygen demand and nutrient loading of the water bodies, promoting toxic algal blooms and leading to a destabilized aquatic ecosystem (Morrison et al, 2001; DWAF and WRC, 1995). High or low pH values in a river have been reported to affect aquatic life and alter toxicity of other pollutant in one form or the other (DWAF, 1996c). Low $\mathrm{pH}$ values in a river for examples impair recreational uses of water and effect aquatic life. A decrease in $\mathrm{pH}$ values could also decrease the solubility of certain essential element such as selenium, while at the same time low $\mathrm{pH}$ increases the solubility of many other element such as Al, B, $\mathrm{Cu}, \mathrm{Cd}, \mathrm{Hg}, \mathrm{Mn}$ and $\mathrm{Fe}$ (DWAF, 1996c). High nitrate concentrations are frequently encountered in treated wastewater, as a result of ammonium nitrogen. High nitrate levels in wastewater could also contribute to eutrophication effects, particularly in freshwater (OECD, 1982). Many workers have been reported to have potential health risk from nitrate in drinking water above threshold of $45 \mathrm{mg} /$ I, which may give rise to a condition known as methaemoglobinemia in infants and pregnant 
women (Speijer, 1996).Biological oxygen demand (BOD) measure the amount of oxygen requires by bacteria for breaking down to simpler substances the decomposable organic matter present in any water, wastewater or treated effluent. It is also taken as a measure of the concentration of organic matter present in any water. The greater the decomposable matter present, the greater the oxygen demand and the greater the BOD values (Ademoroti, 1996; Standard methods, 1998). Electrical conductivity of water is a useful and easy indicator of its salinity or total salt content. Wastewater effluents often contain high amounts of dissolved salts from domestic sewage. High salt concentrations in waste effluents however, can increase the salinity of the receiving water, which may result in adverse ecological effects on aquatic biota (Ademoroti, 1996). Vegetables are staple part of human meals taken as food in raw and cooked forms In view of the continues used of wastewater for the irrigation of vegetable crops in these area of Dheradun, this study is aimed to assess the levels of some physicochemical parameters in wastewater samples from the Dheradun .

\section{MATERIALS AND METHOD}

\section{Sample area and Sampling Points}

Wastewater samples were collected from the Dheradun industrial area for the analysis of physicochemical parameters. Measurement points for the sampling were designated as N1 to N4. Wastewater samples were collected at the discharge point from old ancient walled city designated as $\mathrm{N} 1 ; 200$ metres away from the ancient walled city (N2); and at 500metres along the Sabon -Gari discharged point from the ancient walled city (N3); N4 was located at Selaqui Paonta sahib Road.

\section{Sample Collection}

Wastewater samples were collected in plastic containers previously cleaned by washing in non-ionic detergent, rinsed with tap water and later soaked in $10 \% \mathrm{HNO}_{3}$ for 24 hours and finally rinsed with deionised water prior to usage.

During sampling, sample bottles were rinsed with sampled water three times and then filled to the brim at a depth of one meter below the wastewater from each of the four designated sampling Points (N1 to N4). The samples were labeled and transported to the laboratory, stored in the Refrigerator at about $4^{\circ} \mathrm{C}$ prior to analysis. Wastewater were also collected for Analysis. Samples were collected between the periods November 2010 to Aug.2011

\section{Determination of Physicochemical pollutant indicators}

All field meters and equipment were checked and calibrated according to the manufacturer's Specifications. The $\mathrm{pH}$ meter was calibrated using $\mathrm{HACH}$ (1997) buffers of $\mathrm{pH} 4.0$, 7.0 and 10.0. Dissolved oxygen (DO) meter was calibrated prior to measurement with the appropriate traceable calibration solution $(5 \% \mathrm{HCl})$ in accordance with the manufacturer's instruction. The spectrophotometers (HACH DR2010) for anions determination were checked for malfunctioning bypassing standard solutions of all the parameters to be measured; Blank samples (deionized water) were passed between every three measurements of wastewater samples to check for any eventual contamination or abnormal response of equipment .The dependent variables analyzed were $\mathrm{pH}$, temperature, dissolved oxygen, total dissolved solid, nitrate, sulphate, phosphate and heavy metals concentration. Standard methods were followed in determining the above variables (APHA, 1998). In-situ measurements for some of the parameters, $\mathrm{pH}$ and temperature $\left({ }^{\circ} \mathrm{C}\right)$ were measured using WTW pH Electrode Sen Tix 41. Dissolved oxygen was measured with Jenway Model 9070 waterproof meter. Conductivity /TDS meter (Hach model C0150) was used to measure the conductivity and total dissolved solids of the water samples. The power key and the conductivity key of the conductivity/TDS meter were switched on, and the meter was also Temperature adjusted; the instrument was calibrated with $0.001 \mathrm{M} \mathrm{KCl}$ to give a value of $14.7 \mu \mathrm{S} / \mathrm{m}$ at $25^{\circ} \mathrm{C}$. The probe was dipped below the surface of the wastewater and surface water. Time was allowed for the reading to be stabilized and reading was recorded. The key was then changed to TDS key and recorded. The probe was thoroughly rinsed with distilled water after each measurement. Levels of turbidity and total suspended solid of the wastewater samples were determined using standard procedures approved by AOAC (1998). The biological oxygen demand 
determination of the wastewater samples in $\mathrm{mg} / \mathrm{l}$ was carried out using standard methods described by Ademoroti (1996). The dissolved oxygen content was determined before and after incubation. Sample incubation was for 5 days at $20^{\circ} \mathrm{C}$ in BOD bottle.

Physicochemical Determination of Pollutants in Wastewater Dheradun Industrial area.BOD was calculated after the incubation periods. Determination of chemical oxygen demand was carried out using closed reflux method as described by Ademoroti (1996).

\section{Digestion of Wastewater Samples for Heavy Metals Determination}

The wastewater samples were digested as follows. The sample, $100 \mathrm{~cm}^{3}$ was transferred into a beaker and $5 \mathrm{ml}$ concentrated $\mathrm{HNO}_{3}$ was added. The beaker with the content was placed on a hot plate and evaporated down to about $20 \mathrm{ml}$. The beaker was cool and another $5 \mathrm{ml}$ concentrated $\mathrm{HNO}_{3}$ was also added. The beaker was covered with watch glass and returned to the hot plate. The heating was continued, and then small portion of $\mathrm{HNO}_{3}$ was added until the solution appeared light coloured and clear. The beaker wall and watch glass were washed with distilled water and the sample was filtered to remove any insoluble materials that could clog the atomizer. The volume was adjusted to $100 \mathrm{~cm}^{3}$ with distilled water (Ademoroti, 1996). Determination of heavy metals in the wastewater samples was done using Atomic Absorption Spectrophotometer (AAS, Unicom 969) as described in the manufacturer' instruction manual.

\section{Elemental Analysis of Digested Samples}

Determination of heavy metals (copper, cobalt chromium, iron, manganese, magnesium, nickel Cadmium, and lead) was made directly on each final solution using Perkin-Elmer Analyst 300 Atomic Absorption Spectroscopy (AAS) as described by Floyd and Hezekiah (1997). Flame emission Spectrometer (FES) Gallenkamp (FGA330) was used to determine sodium ( $\mathrm{Na})$, potassium (K) and Calcium (Ca).

\section{Determination of Nitrate, Nitrite, Sulphate and Phosphate in the Wastewater Samples}

The concentration of nitrate, nitrite, sulphate and phosphate were determined using DR/2010 HACH Portable Data Logging Spectrophotometer. The spectrophotometers were checked for malfunctioning by passing standard solutions of all the parameters to be measured; blank samples (deionized water) were passed between every three measurements of water samples to check for any eventual contamination or abnormal response of equipment.

Nitrate as nitrogen was determined by the cadmium reduction metal method 8036[Standard Methods, 1976, DWAF, 1992]. The cadmium metal

Table 1: Concentration of Physicochemical Parameters in wastewater samples from Dheradun Industrial area waste water, Uttrakhand state

\begin{tabular}{lllll}
\hline $\begin{array}{l}\text { Parameters Sampling } \\
\text { Points }\end{array}$ & N1 & N2 & N3 & N4 \\
\hline pH & $9.94 \pm 1.32$ & $8.94 \pm 2.03$ & $10.34 \pm 1.43$ & $9.54 \pm 0.54$ \\
Temp $\left({ }^{\circ} \mathrm{C}\right)$ & $32.34 \pm 0.32$ & $31.11 \pm 0.11$ & $36.34 \pm 2.94$ & $33.34 \pm 1.44$ \\
Turbidity $(\mathrm{NTU})$ & $36.33 \pm 2.13$ & $34.23 \pm 2.32$ & $42.22 \pm 3.10$ & $33.34 \pm 2.01$ \\
$\mathrm{COD}(\mathrm{mg} / \mathrm{l})$ & $564.32 \pm 5.43$ & $512.45 \pm 7.21$ & $698.11 \pm 6.45$ & $531.05 \pm 9.23$ \\
$\mathrm{BOD}(\mathrm{mg} / \mathrm{l})$ & $254.11 \pm 2.32$ & $223.43 \pm 4.23$ & $341.11 \pm 4.34$ & $245.22 \pm 2.77$ \\
DO $(\mathrm{mg} / \mathrm{l})$ & $7.43 \pm 0.76$ & $6.22 \pm 0.23$ & $8.43 \pm 0.56$ & $6.56 \pm 0.49$ \\
TDS $(\mathrm{mg} / \mathrm{l})$ & $2321.23 \pm 33.23$ & $2210.21 \pm 22.32$ & $2655.43 \pm 16.33$ & $2456.22 \pm 18.90$ \\
TSS $(\mathrm{mg} / \mathrm{l})$ & $1237.12 \pm 12.45$ & $1131.23 \pm 14.32$ & $2673.22 \pm 17.32$ & $2673.22 \pm 17.32$ \\
Conductivity $\left(\mu \mathrm{Scm}^{-3}\right)$ & $1123.41 \pm 10.21$ & $1021.17 \pm 14.32$ & $1534.21 \pm 12.43$ & $1477.32 \pm 14.32$ \\
Sulphate $(\mathrm{mg} / \mathrm{l})$ & $172.32 \pm 0.83$ & $154.33 \pm 1.02$ & $252.21 \pm 1.32$ & $212.22 \pm 0.77$ \\
Nitrate $(\mathrm{mg} / \mathrm{l})$ & $223.21 \pm 1.21$ & $211.43 \pm 0.34$ & $284.33 \pm 1.74$ & $234.56 \pm 1.92$ \\
Phosphate $(\mathrm{mg} / \mathrm{l})$ & $110.45 \pm 0.42$ & $103.23 \pm 0.11$ & $164.22 \pm 0.56$ & $153.22 \pm 0.67$ \\
\hline
\end{tabular}


in the added reagent reduced all nitrate in the sample to nitrite; while sulphate was determined by using Sulfa Ver methods 8051 [Standard methods,1976., DWAF, 1992].126 J.C.Akan, F.I. Abdulrahman, G.A.Dimari and V.O.OgugbuajaThe levels of the physicochemical parameters are presented in Table 1. From the results of this study the levels of $\mathrm{pH}$ varied between $9.94 \pm 1.32$ and $8.94 \pm 2.03$ for point $\mathrm{N} 1$ and $\mathrm{N} 2$, and $10.34 \pm 1.43$ to9.54 \pm 0.54 for point N3 and N4 in the wastewater respectively. Generally point N3 shows the highest concentration followed by $\mathrm{N} 1$, while point $\mathrm{N} 2$ shows the least concentration. The mean $\mathrm{pH}$ values recorded for all the sampling point were above the WHO pH tolerance limit of between $6.00-9.00$ for wastewater to be discharged into channel into stream with exception of point N2.

Physicochemical Determination of Pollutants in Wastewater along Dheradun Industrial waste water, Uttrakhand state.

Temperature is basically important for its effect on other properties of wastewater. Average

Temperature of wastewater under investigation is $42.34 \pm 0.32^{\circ} \mathrm{C}$ for $\mathrm{N} 1 ; 41.11 \pm 0.11^{\circ} \mathrm{C}$ for N2; $46.34 \pm 2.94{ }^{\circ} \mathrm{C}$ for $\mathrm{N} 3$ and $43.34 \pm 1.44{ }^{\circ} \mathrm{C}$ for N4. The results indicate that some reactions could be speeded up by the discharge of this wastewater into stream. It will also reduce solubility of oxygen and amplified odour due to anaerobic reaction (less oxygen). These values were higher than WHO standard of $40^{\circ} \mathrm{C}$ for discharged of wastewater into stream. Similarly turbidity values were in the mean of 36.33 $\pm 2.13 \mathrm{NTU}$ for $\mathrm{N} 1 ; 34.23 \pm 2.32 \mathrm{NTU}$ for N2; $42.22 \pm 3.10 \mathrm{NTU}$ for N3 and $33.34 \pm 2.01 \mathrm{NTU}$ for N4. The values obtained for turbidity in the entire sampling points under study were higher than WHO standard of 5 NTU for discharged of wastewater into stream.

The conductivity values were $1123.41 \pm 10.21{\mu \mathrm{Scm}^{-3}}^{3}$ for $\mathrm{N} 1 ; 1021.17 \pm 14.32$ $\mu \mathrm{Scm}^{-3}$ for $\mathrm{N} 2 ; 1534.21 \pm 12.43 \mu \mathrm{Scm}^{-3}$ for $\mathrm{N} 3$ and $1477.32 \pm 14.32 \mu \mathrm{Scm}^{-3}$ for N4 (Table 1). Conductivity of water which is a useful indicator of its salinity or total salt content is high in the wastewater from the dheradun industrial wastewater channel. This result is not surprising, since wastewater from domestic sewage often contain high amounts of dissolved salts. The mean conductivity values for all the sampling point were higher than the WHO guideline values of $1000 \mu \mathrm{Scm}^{-3}$ for the discharge of wastewater through channel into stream .The total suspended solids (TSS) concentrations were $1237.12 \pm 12.45$ for $\mathrm{mg} / \mathrm{l} \mathrm{N} 1 ; 1131.23 \pm 14.32 \mathrm{mg} / \mathrm{l}$ for N2; $2673.22 \pm 17.32 \mathrm{mg} / \mathrm{l}$ for N3 and $2673.22 \pm 17.32$ $\mathrm{mg} / \mathrm{l}$ for N4 (Table 1).Literature classified wastewater TSS as follows: TSS less than $100 \mathrm{mg} /$ I as weak, TSS greater than $100 \mathrm{mg} / \mathrm{l}$ but less than $220 \mathrm{mg} / \mathrm{l}$ as medium and TSS greater than $220 \mathrm{mg} /$ I as strong wastewater. Results of the study show that wastewater from the wastewater channel can be classified as strong Wastewater and cannot be discharged into stream.

The mean concentration of Total dissolved solid (TDS) in the Dheradun industrial wastewater channel wastewater channel are presented in Table 1. The concentration of TDS is $2321.23 \pm 33.23 \mathrm{mg} /$ I for N1; 2210.21 $\pm 22.32 \mathrm{mg} / \mathrm{l}$ forN2; 2655.43 \pm 16.33 $\mathrm{mg} / \mathrm{l}$ for N3 and $2456.22 \pm 18.90 \mathrm{mg} / \mathrm{l}$ for N4. These values obtained for TDS in all the sampling points were higher than WHO standard of $2000 \mathrm{mg} / \mathrm{l}$ for the discharged of wastewater into surface water. The concentrations of nitrate, sulphate and phosphate in all the sampling points varied between $211.43 \pm 0.34$ to $284.33 \pm 1.74 \mathrm{mg} / \mathrm{l}$ for nitrate; $154.33 \pm 1.02$ to $252.21 \pm 1.32 \mathrm{mg} / \mathrm{l}$ for sulphate and103.23 \pm 0.11 to $164.22 \pm 0.56 \mathrm{mg} / \mathrm{l}$ for phosphate respectively (Table 1). High concentration of nitrate, sulphate and phosphate were observed in point N3, while low concentrations were observed for pointN2. The levels of nitrate exceeded the WHO limits of $45 \mathrm{mg} /$ I and South Africa guideline of $0.25 \mathrm{mg} / \mathrm{l}$ for nitrate in wastewater, while sulphate was below the WHO limit of $250 \mathrm{mg} / \mathrm{l}$ for the discharged of waste water into river. The levels of phosphate in the entire sampling point were higher than the WHO limit of $5 \mathrm{mg} / \mathrm{l}$ for the discharged of wastewater into river. The levels of nitrate may give rise to128 J.C.Akan, F.I.Abdulrahman, G.A.Dimari and V.O. Ogugbuaja methaemoglobinemia, also the levels of nitrate reported in this study in addition to phosphate levels can cause euro phication and may pose a problem for other uses. Dissolved oxygen (DO) values obtained for point N1 to N2 varied between $6.22 \pm 0.23$ to $8.43 \pm 0.56 \mathrm{mg} / \mathrm{l}$ as shown in Table 1 . 
The DO is a measure of the degree of pollution by organic matter, the destruction of organic substances as well as the self purification capacity of the water body. The standard for sustaining aquatic life is stipulated at $5 \mathrm{mg} / \mathrm{l}$ a concentration below this value adversely affects aquatic biological life, while concentration below $2 \mathrm{mg} / \mathrm{l}$ may lead to death for most fishes (Chapman, 1997). The DO level at point $\mathrm{N} 1$ to $\mathrm{N} 4$ was above these levels .An indication of organic oxygen demand content of wastewater can be obtained by measuring the amount of oxygen required for its stabilization either as BOD and COD. Biological Oxygen demand (BOD) is the measure of the oxygen required by microorganisms whilst breaking down organic matter. While Chemical Oxygen Demand (COD) is the measure of amount of oxygen required by both potassium dichromate and concentrated sulphuric acid to breakdown both organic and inorganic matters. BOD and COD concentrations of the wastewater were measured, as the two were important in unit process design. The wastewater has an average COD concentration of $512.45 \pm 7.21$ to698.11 $\pm 6.45 \mathrm{mg} / \mathrm{l}$ for point N2 to N4 (Table 1 ). BOD concentration of the wastewater obtained for point $\mathrm{N} 1$ to $\mathrm{N} 4$ ranged between $223.43 \pm 4.23$ to $341.11 \pm 4.34 \mathrm{mg} / \mathrm{l}$ respectively. The concentrations of $B O D$ and $C O D$ in all the sampling point were higher than the WHO values of $50 \mathrm{mg} / \mathrm{l}$ and $1000 \mathrm{mg} /$ I for the discharged of wastewater into stream. High COD and BOD concentration observed in the waste water might be due to the use of chemicals, which are organic or inorganic that are oxygen Demand in nature .The results for elemental concentration in wastewater samples from the dheradun industrial wastewater channel wastewater channel for different sampling points are presented in Figure 1. The composition of metals in the wastewater samples ranged from 2.87 to $5.22 \mathrm{mg} / \mathrm{l}$ for $\mathrm{Mn} ; 4.57$ to $7.45 \mathrm{mg} / \mathrm{l} \mathrm{Mg} ; 2.32$ to $3.78 \mathrm{mg} / \mathrm{l} \mathrm{Cu} ; 1.00$ to 3.58 $\mathrm{mg} / \mathrm{l} \mathrm{Cd} ; 1.23$ to $2.87 \mathrm{mg} / \mathrm{l} \mathrm{Pb} ; 2.34$ to $5.23 \mathrm{mg} / \mathrm{l} \mathrm{Co}$; 14.56 to $21.45 \mathrm{mg} / \mathrm{Fe} ; 1.56$ to $4.33 \mathrm{mg} / \mathrm{l} \mathrm{Cr} ; 11.65$ to $18.45 \mathrm{mg} / \mathrm{l} \mathrm{Ni} ; 20.91$ to $32.94 \mathrm{mg} / \mathrm{l} \mathrm{Na} ; 19.43$ to $27.34 \mathrm{mg} / \mathrm{l} \mathrm{K}$ and 9.56 to $16.93 \mathrm{mg} / \mathrm{l} \mathrm{Ca}$ for point N1 to N4. The concentrations of heavy metals in the wastewater channel are in the following order $\mathrm{Na}>$ $\mathrm{K}>\mathrm{Fe}>\mathrm{Ni}>\mathrm{Ca}>\mathrm{Mg}>\mathrm{Co}>\mathrm{Mn}>\mathrm{Cr}>\mathrm{Cu}>\mathrm{Cd}>\mathrm{Pb}$. From the result of these study the concentrations of all the parameters study (Table 1 ) are in the following order $\mathrm{N} 1>\mathrm{N} 2<\mathrm{N} 3>\mathrm{N} 4$. This variation is due to the fact that point $\mathrm{N} 1$ is the discharged point from Bindal bridge and decrease towards point N2. While the high values at point N3 is due to the discharged of wastewater from Pharma city into the Dheradun industrial which might increase the concentration of these parameters, and finally decreases toward point N4 due to sedimentation and dilution .Physicochemical Determination of Pollutants in Wastewater along Dheradun Industrial waste water, Uttrakhand state.

\section{CONCLUSION}

From the data collected from this research, the physicochemical parameters monitored in point N1, N2, N3 and N4 showed high levels of all the parameters. This must be as a result of the nature of Wastewater from the Pharma city and Sara industry. Point N3 showed the highest concentration of the physicochemical parameter, while point N2 shows the lowest values. WHO, this high values is due to the used of untreated wastewater from the industrial area for the Irrigation of these vegetables. Accordingly, wastewater from all the sampling points are polluted as can be observed from the results obtained.

\section{REFERENCES}

1. Abdulla, M. and Chmielnicka, J. New aspects on the distribution on the distribution and Metabolism on essential trace elements after dietary exposure toxic metals. Biol. TraceElement Res. 23: 25-53 (1990).

2. Ademoroti, C.M.A. Standard method for water and Effluents Analysis. Foludex press Ltd,
Ibadan pp. 22-23, 44-54, 111-112 (1996).

3. Anikwe, M.A.N. and Nwobodo, K.C.A. Long term effect of municipal waste disposal on soil properties and productivity of sites used for urban agriculture in Abakaliki, Nigeria. Bioresources Technol. 83: 241-251 (2006).

4. AOAC. Official methods of analysis of the 
Association of Official Analytical Chemist. Alexandria, VA: Association of Official Analytical Chemists. 432-444 (1998).

5. APHA. Standard methods for the examination of water and wastewater. 18th Edition. American Public health Association, Washington, DC pp 45-60 (1998).

6.. Chapman, D. Water Quality Assessment. A Guide to the use of Biota, Sediments and water in Environmental Monitoring. Second Edition. E\& FN Spon, London. File: A// :Hydrology and Water Quality of Lake Merced.htm (1997).

7. DWAF Analytical Methods Manual, TR 151. Department of Water Affairs and Forestry, Pretoria (1992).

8. DAWF and WRC (1995) South Africa Water Quality Guideline 1: Domestic water use (2nd edn) Department of Water Affairs and Forestry, Pretoria.

9. DWAF, South Africa water quality Guidlines. 7: Aquatic Ecosystems (1st Edn) Department of water Affairs and forestry, Pretoria (1996c).

10. Floyd, W.B. and Hezekiah .S. Analysis of coal ash by atomic absorption spectrometric and spectrophotometric methods. In: Method for sampling and inorganic Analysis of Coal. USA. Geological Survey Bulletin 1823 Golightly D.W and Simon F.O. (Ed). 1-20 (1997).

11. HACH. Water Analysis Handbook, 3rd edition, HACH Company, Loveland, Colorado, USA (1997).

12. Hunt, J. and Turner, M.K. A survey of nitrite concentrations in retail fresh vegetables. Food Additive and Contaminations. 11(3): 327-332 (1994).

13. Kenneth Helrich, Official Method of Analysis of AOAC 5th Edition.AOAC Inc. Arlington USA Pp56-58. 22 (1990).

14. Kocak, S., Tokusoglu, O. and Aycan, S. Some heavy metal and trace essential element Detection in canned vegetable foodstuffs by differential pulse polarography (DPP), Electronic J. Environ. Agric. Food Chem. 4: 871-878 (2005).

15. Konofal, E., Lecendreux, M., Arnulf, I. and Mouren, M.C. Iron deficiency in children with attention-deficit/hyperactivity disorder. Arch.
Pediatr. Adolesc. Med. 158: 1113-1115 (2004).

16. Liu, W.H., Zhao, J.Z., Ouyang, Z.Y., Soderlund, L. and Liu, G.H. Impacts of sewage irrigation on heavy metals distribution and contamination in Beijing, China. Environ. Int. J. 31: 805-812(2005).

17. Morrison, G. O., Fatoki, O.S and Ekberg, A. Assessment of the impact of point source pollution from the Keiskammahoek sewage treatment plant on the keiskamma river. Water. SA., 27: 475-480 (2001).

18. Muchuweti, M.J., Birkett, J.W., Chinyanga, E., Zvauya, R., Scrimshaw, M.D., and Lester, J. $N$. Heavy metal content of vegetables irrigated with mixture of wastewater and sewage sludge in Zimbabwe: Implications for human health. Agric. Ecosyst. Environ. 112: 41-48 (2006).

19. OECD, Eutrophication of waters: Monitoring, Assessment and Control. Technical Report, organization for economic Co operation and Development, Paris (1982).

20. Radojevic,M. and Bashkin, V.N. Practical Environmental Analysis. The Royal Society of Chemistry, Cambridge pp 466 (1999).

21. Santamaria, P., Elia, A., Serio, F. and Todaro, E. A suevey of nitrate and oxalate content in retail fresh vegetables. J.Sci. Food. Agric. 79: 1882-1888 (1999).

22. Sharma, R.K., Agrawal, M., and Marshall, F. Heavy metal contamination of soil and vegetables in suburban areas of Varanasi, India. Ecotoxicol. Environ. Safety. J. Doi: 10.1016/jecenv (2007).

23. Speijers, G.J.A. Nitrate in Toxicological evaluation of certain foot additive and contaminats in food, ed, by WHO, Food Additive Series 35, Geneva, pp 325-360.

24. Standard Methods. Standard method for the examination of water and wastewater (14thedn) Jointly published by the American Public Health Association, America Water Works Association and Water Pollution Control Federation, Washington, DC. Pp 68165 (1996).

28. Zhou, Z.Y., Wang, M.J. and Wang J.S. Nitrate and nitrite contamination in vegetables in china. Food. Rev. Int. 16: 61-76 (2000). 